\title{
СВЕДЕНИЯ О ДУАЛИСТИЧЕСКИХ ЕРЕСЯХ И ЯЗЫЧЕСКИХ ВЕРОВАНИЯХ В ШЕСТОДНЕВЕ ИОАННА ЭКЗАРХА
}

В 20-е годы ХХ в. Йордан Иванов, ссылаясь на Шестоднев Иоанна Экзарха, приводит пример бытования дуалистических верований в Болгарии еще во время царствования Симеона Великого. Согласно Иоанну Экзарху (так, как его цитирует Иванов), скверните манихеи и езичниците славяни... не се срамуват да наричат дявола по-стар син ${ }^{1}$ (имеется в виду Сын Бога).

Чтобы оценить эти сведения из Шестоднева, необходимо рассмотреть цитату в контексте интерпретационной стратегии Й. Иванова и обратить внимание на то, каким образом связываются друг с другом приведенные им цитаты. Вот что пишет Иванов:

Още в това време дуализмът ще да е бил спечелил свои български последователи. Йоан Екзарх Български, съвременник на цар Симеона (893-927 г.) укорява на няколко места в съчинението си манихеите и славяните езичници, останали такива и след кръщението на Бориса. Той дори изтъква една от харатерните особености на бъдещото богомилско учение за сатаната, смятан за старши син на Бога:

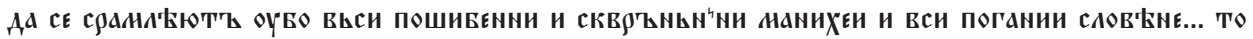

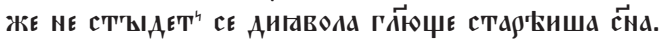

Това показва, че богомилството, като смесица от манихейство, павликянство и масалиянство, е било захванало да се оформя доста рано в България и че за него са знаели писатели, като Йоана Екзарха. ${ }^{2}$

В вводном по отношению к приведенной цитате Иоанна Экзарха предложении болгарский медиевист относит фрагмент (фрагменты?) из Ше-

\footnotetext{
${ }^{1}$ Й. ИвАнов, Богомилски книги и тегенди, фототипно изд., София 1970, p. 20.

2 Ibidem. Й. Иванов не указывает, цитирует ли он по рукописи или по изданию. Можно предположить, что он использовал единственное известное в начале XX в. издание Осипа М. Бодянского, исправленное в 1879 г. А.Н. Поповым. Сf.: О. М. Бодянский, Шестоднев, составленный Иоанном Ексархом Болгарским. По харатейному списку Московской синодальной библиотеки, Москва 1879. Далее цитаты из Шестоднева по изд.: R. AitzetмülleR, Das Hexaemeron des Exarchen Johannes, vol. I-VII, Graz 1958-1975 (cetera: Hexaemeron). Более новое издание с русским переводом по рукописи РГБ, ф. № 173 от XV в. в: Г.С. БАРАНКОВА, В.В. МИЛЬков, Шестоднев Иоанна экзарха Болгарского, Санкт-Петербург 2001. Болгарский перевод в: ЙОАН ЕКЗАРХ, Шестоднев, ed. 2, trans., praef., comment. Н.Цв. КочЕв, София 2000.
} 
стоднева к дуалистическому космогоническому мифу, согласно которому дьявол, создатель материального мира, является первородным сыном Бога, и замечает ниже, что это еретическое учение станет една от характерните особености на бъдещзото богомилско учение за сатаната. Далее, однако, автор книги Богомилски книги и тегенди противоречит сам себе, утверждая, что богомилството, като смесииа от манихейство, павликянство и масалиянство, е било захванало да се оформя доста рано в България, то есть, согласно Й. Иванову, во время Симеона это уже не будущее, а актуальное учение.

Связывание двух староболгарских фраз многоточием предполагает, что они взяты из двух различных мест текста. Иначе говоря, возможно, что да $\mathfrak{c}$ с

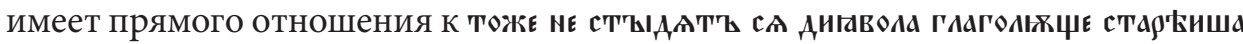
сына, то есть „скверные манихеи“ и прежде всего „язычники славяне“ веровали во что-то другое, а не в то, что дьявол - это старший сын Бога.

На это несоответствие обращает внимание Милан Лос³, который, используя издание О.М. Бодянского, указывает, что обе фразы взяты из разных мест Шестоднева и относятся к двум различным религиозным феноменам. В первой осуждаются прежде всего языческие, но также и манихейские верования в солнце как изначально существовавшее божество, а не как в небесное светило, созданное и подчиненное христианскому Богу:

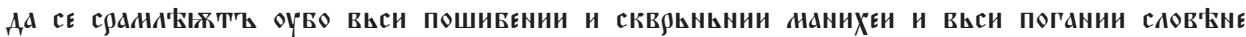

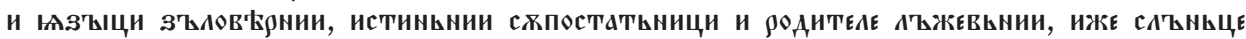

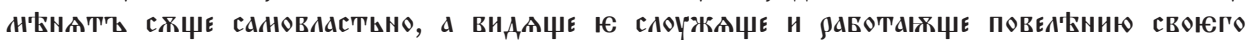
творьца. ${ }^{4}$

Второй фрагмент, цитируемый М. Лосом, в котором говорится о „еретиках“ и „еретических извращениях“ вообще, уже прямым образом относится к неоманихейской средневековой космогонии: Иоанн Экзарх изобличает дуалистические представления о сатане как о первородном сыне Бога, как о демиурге и создателе материального мира:

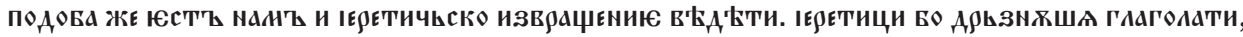

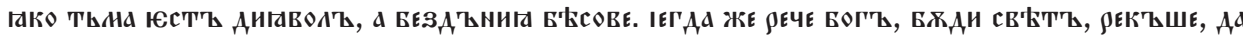

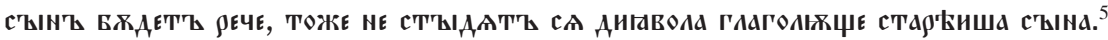

Корректировка интерпретации Й. Иванова становится для М. Лоса стимулом для основательного исследования проблемы первородства сатаны

\footnotetext{
${ }^{3} \mathrm{M}$. Loos, Le prétendu témoignage d'un traité de Jean Exarque intitulé „Šestodnev” et relatif aux Bogomiles, Bsl 13, 1952, p. 59-88.

${ }^{4}$ Ibidem, p. 61, n. 12. Hexaemeron, IV, p. 121-123.

${ }^{5}$ Ibidem, p. 64, прим. 23. Hexaemeron, I, p. 107-109.
} 
в одной более поздней статье, в которой также приводится больше параллелей с византийскими антиеретическими сочинениями ${ }^{6}$. Текстологические наблюдения чешского ученого используются в исследованиях, отрицающих возможность того, что богомилизм появился уже как сформировавшаяся доктрина до середины X в. ${ }^{7}$ Большинство авторов рассматривает первый фрагмент как свидетельство сохранившихся языческих верований среди новокрещенного болгарского народа ${ }^{8}$, а второй - как доказательство распространения неоманихейских средневековых ересей (мессалианство, павликианство) в болгарских землях после крещения во второй половине IX в. ${ }^{9}$

Попытки реконструировать „предысторию“ богомилизма показывают значение созданных до второй половины Х в. греческих и славянских текстов (в том числе - и Шестоднева) для описания и анализа неоманихейской доктрины в контексте более ранних гетеродоксальных учений на Балканском полуострове и в малоазиатских провинциях Византии. При подготовке двуязычного издания славянских источников по истории средневековых дуалистических ересей на Балканах ${ }^{10}$ оказалось, что в Шестодневе можно открыть намного больше следов полемики с еретическими дуалистическими представлениями, которые до настоящего времени не были объектом отдельного анализа. Более того, греческие параллели в издании Рудольфа Айцетмюллера дают возможность определить, какие из антиеретических фрагментов являются переводом или компиляцией, а какие - оригинальными дополнениями Иоанна Экзарха ${ }^{11}$. Именно такая цель ставится в настоящей статье: привести по возможности полный список фрагментов, где упоминаются «еретики», «манихеи», «язычники», «язычники-славяне»; сравнить эти фрагменты с их греческими соответствиями (там, где они есть); использовать староболгарские тексты (прежде всего те из них, которые имеют

\footnotetext{
${ }^{6}$ M. Loos, Satan als erstgeborener Gottes (ein Beitrag zur Analyse des bogomilischen Mythus), BBg 3, 1969, s. 23-35. Cf.: Idem, Dualist Heresy in the Middle Ages, Praha 1974.

${ }^{7}$ Cf.: Д. ДРАГОјЛОвИЋ, Богомилство на Балкану и у Малој Азији. II. Богомилство на православном истоку, Београд 1982, р. 95.

${ }^{8}$ См. также: Д. АНГЕЛов, Богомилството в България, София 1969, р. 110-111 и прим. 16 с указанной более старой литературой: Въпреки полаганите усилия от страна на ибрквата езическите вярвания мъчно могли да се изкоренят. За това свидетелствува един текст от Шестоднева на Йоан Екзарх. В това съчинение, съставено между 915-927 г., писателят се обрвща с укорни думи към „поганите славяни и зловерните народи“, които считали по подобие на манихеите, че сльнцето не било подчинено на божията воля и не изпвлнявало неговите нареждания, а се движело, както те мислели, от само себе си (ижє санцє нинєтт соүцє сановластьно).

${ }^{9}$ Наистина в "Шестоднева" името на павликяните не е споменато изрично, но може да се предположи, че те се крият под общото означение „манихеи“, срешу кочто насочва свочте стрели старобблгарският писател, Д. Ангелов, Богомилството..., p. 136.

${ }^{10}$ G. Minczew, M. Skowronek, J.M. Wolski, Słowiańskie źródła do dziejów średniowiecznych herezji dualistycznych na Bałkanach (в печати).

11 Наличие или отсутствие греческих соответствий отмечаются следующим образом: Hexaemeron, IV, p. 121-123, гр.+ или Hexaemeron, II, p. 75, гр.-.
} 
характер оригинальных добавлений и свободных компиляций) для интерпретации некоторых элементов гетеродоксальных доктрин, общих для манихейства, павликианства, мессалианства и богомилизма. Интересно также проследить значение произведения Иоанна Экзарха как источника для более поздних антиеретических сочинений, в которых могут быть найдены скрытые или прямые цитаты из Шестоднева.

Иоанн Экзарх говорит о «еретиках», «манихеях», «язычниках», «язычниках-славянах» в более чем 30 фрагментах различного объема в тексте. Староболгарский автор следует образцам, на основе которых создает свое сочинение - греческим гексамеронам. Согласно византийским ересиологам со времен Иоанна Экзарха (а также более ранним и более поздним) самыми опасными дуалистическими отклонениями от ортодоксальной веры, связанными друг с другом, являются два: 1) искажение библейского рассказа о сотворении посредством введения второго творца (демиурга) материального мира, и 2) отклонения от догмата о Св. Троице посредством введения элементов субординации между Отцом, Сыном и Св. Духом. К этим двум основным отклонениям от догматики Восточной Церкви, присутствующим в староболгарском Шестодневе, можно добавить еще несколько обвинений против верований дуалистов, большинство из которых связано с раннехристианскими христологическими ересями, но находит отражение также и в позднейших неоманихейских доктринах (например, отрицание культа Богородицы).

В одном из переведенных с греческого фрагментов Шестоднев осуждает тех „еретиков“, которые отрицали православную литургию или скорее отдельные элементы Литургии Верных - это еще одна особенность неоманихейских учений, согласно которым православный ритуал является „многословием“, а единственная молитва, санкционируемая новозаветными текстами, - это „Отче наш“.

Отдельного внимания заслуживает известный фрагмент Шестоднева, приведенный в трудах Й. Иванова и М. Лоса, в котором говорится о сохранившихся остатках языческих верований среди славян и манихеев. При более внимательном прочтении Шестоднева по изданию Р. Айцетмюлера оказалось, что солярный культ, связанный с манихейскими верованиями, упоминается в еще одном фрагменте, не имеющем греческого соответствия. Эти сведения имеют действительно важное значение для исследования следов языческих культов в религии балканских славян, но они должны рассматриваться также в более широком контексте отрицательного отношения авторов шестодневов к проникнувшим из античности в христианский мир астрологическим знаниям и предсказаниям, основанным на вере во влияние небесных сил на человеческую судьбу.

Переводческо-компилятивная техника Иоанна Экзарха основывается на внимательном прочтении и переосмыслении греческих шестодневов: пе- 
реводя те части, которые представлялись ему наиболее важными, он добавляет свои оригинальные дополнения, своего рода комментарий, „заметки на полях“ ко греческому тексту там, где он выглядел для него, возможно, недостаточно ясным или нуждающимся в дополнительной богословской аргументации.

\section{1. Дуалистическая космогония и космология - сотворение мира и сатаны как первородного сына Бога.}

Одно из наиболее часто встречающихся обвинений против приверженцев некоторых позднеантичных гностических и средневековых неоманихейских доктрин связано с верой гетеродоксов в демиурга - творца материального мира. Ересиологи подчеркивают несоответствие между библейским рассказом о сотворении и «мудрствованиями» еретиков. Ветхозаветная космогония строго монотеистична: Бог ex nihilo создает гармоничный видимый и невидимый мир, а по своему образу и подобию - интегрального «материального» и «духовного» Адама; согласно гностикам и позднейшим дуалистическим доктринам, невидимое, «духовное» и доброе - по презумпции творение невидимого Бога, а несовершенный, материальный мир - творение злого демиурга (ветхозаветный Ягве/Саваоф, сатана, дьявол), который является также создателем «материального» Адама.

Защита библейской космогонии и космологии имеет свое место и в греческих шестодневах, используемых Иоанном Экзархом в его компиляции. Полемика с дуалистическими концепциями о сотворении особенно видна в Слове о первом дне, но также заметна и в других местах текста - Словах о третьем и шестом днях. Согласно Шестодневу, текст из Быт. 1:1 въ начлмо

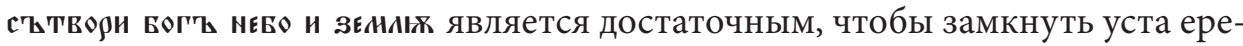
тикам ${ }^{12}$. Манихеи извращают слово Божье, утверждая, что злой демиург

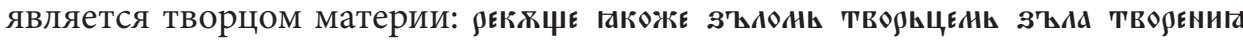
сжть $^{13}$. Иоанн Экзарх защищает ортодоксальное учение, доказывая, что все творение - это дело доброго Творца, а не злого демиурга: нє инћнь творьцєнь

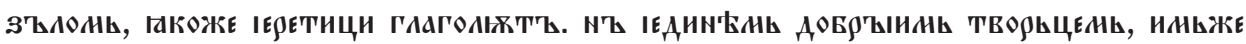

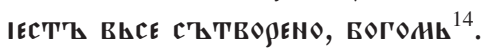

В Слове о шестом дне изобличается унаследованное из древнего гностицизма еретическое представление о том, что душа выпала из бесплотного

\footnotetext{
${ }^{12}$ Hexaemeron, III, p. 53, rp.-

${ }^{13}$ Hexaemeron, III, p. 73-75, гр.-

${ }^{14}$ Hexaemeron, I, p. 209-211, rp.-
} 
мира и в результате какой-то «космической катастрофы» вошла в человече-

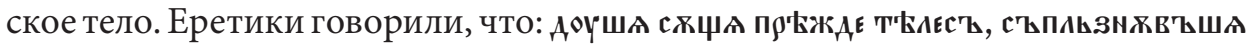

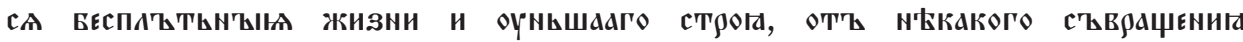

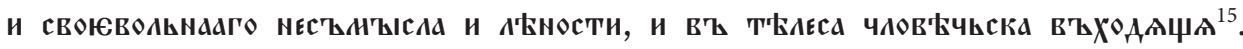
А в Слове о пятом дне изобличается манихейская вера в то, что „земля

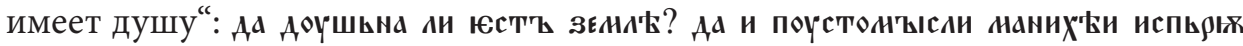

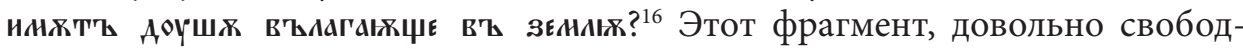
ный перевод с греческого (Е

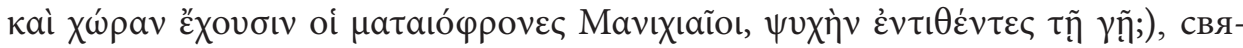
зан с приведенной выше цитатой из Слова о шестом дне. Земля, символ презренной материи, является гностической „темницей души“ - местом, куда божественная искра попала после космической катастрофы, и в то же время началом ее пути (посредством последовательных перерождений) обратно к плероме ${ }^{17}$.

Сопоставление староболгарских фрагментов, посвященных сотворению, с византийскими шестодневами показывает интересную закономерность: большинство из них не имеет греческих соответствий ${ }^{18}$. Оригинальность добавлений свидетельствует не только о хорошем богословском образовании Иоанна Экзарха. Можно предположить, что проникнувшие в Болгарию после крещения неоманихейские доктрины были уже широко распространены, и реакция староболгарского книжника против основного дуалистического космогонического мифа является следствием личных наблюдений, переосмысления и интерпретации почерпнутых из византийской ересиологической литературы сведений.

В приведенных фрагментах упоминается в общих словах о „еретиках”, „еретическом извращении”. В нескольких местах в оригинальных добавлениях Иоанна Экзарха упомянуто, что дуалистический миф о сотворении -

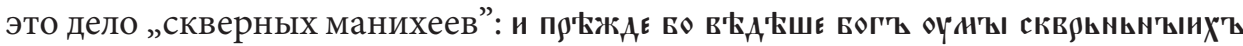

\footnotetext{
${ }^{15}$ Hexaemeron, VI, p. 105-107, гр.-

${ }^{16}$ Hexaemeron, V, p. 105, гр.+

${ }^{17}$ О гностических и манихейских концепциях о „падении души“ существует огромная литература, см. напр.: G. Quispel, Gnoza, trans. B. KiтA, Warszawa 1988, p. 73-152; H. JonAs, Religia gnozy, trans. M. Klimowicz, Kraków 1994, p. 127-144; K. Rudolph, Gnoza. Historia i istota późnoantycznej formacji religijnej, trans. G. Sowiński, Kraków 1995, p. 187sqq; S. Runciman, The Medieval Manichee. A Study of the Christian Dualist Heresy, Cambridge 2003, p. 6-8; M. Eliade, Historia wierzeń i idei religijnych, vol. III, trans. S. ToKARsкI, Warszawa 2008, p. 295-321; см. также: Y. Stoyanov, The Other God. Dualist Religions from Antiquity to the Cathar Heresy, New HavenLondon 2000, p. 28-34 с указанной там более ранней литературой.

${ }^{18}$ По изданию Р. Айцетмюллера. Можно предположить, что Иоанн Экзарх знал и некоторые другие источники. Но так как это не доказано (по крайней мере, в настоящий момент) основываясь на издании австрийского палеослависта, здесь мы будем рассматривать староболгарские фрагменты без греческих соответствий как оригинальные дополнения староболгарского писателя.
} 
нанихєи ${ }^{19}$, но в переводных частях определение „манихеи“ используется на-

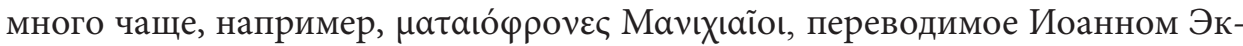
зархом как поустолъысли наних'ки ${ }^{20}$. Употребление лексемы „манихей“ в греческих шестодневах и в славянском переводе дает основание некоторым ученым утверждать, что в данном случае идет речь о других неоманихейских учениях, прежде всего - о павликианстве, оказавшем влияние на доктрину богомилов. Так утверждают, например, Димитър Ангелов, и Драголюб Драгойлович ${ }^{21}$.

В отношении оригинального добавления староболгарский писатель следует греческой традиции, повторяя анахронизм, характерный для византийских антиеретических сочинений. После VI в. манихейство перестает быть проблемой для Восточной Церкви, многовековая борьба завершается победой ортодоксии. Независимо от этого, в более поздних юридических документах и литургических памятниках все еще предусматривается, что раскаявшиеся манихеи должны быть приобщены к Церкви по чину приобщения язычников, то есть через повторное крещение 22 . Но в данном случае речь идет скорее о повторении более древних церковно-юридических документов или литургических памятников, так как в конце VII в. манихейская смута - это уже лишь плохое воспоминание, а перед империей появляются новые вызовы: иконоборчество и борьба с проникнувшими с Востока или возникнувшими на Балканском полуострове дуалистическими учениями павликианством, мессалианством, а позднее - богомилизмом. Вопреки тому, что „реальных“ манихеев уже давно нет, греческие и славянские рукописи с VIII вплоть до XV-XVI вв. продолжают осуждать „трижды проклятую манихейскую ересь“, изобличая в сущности другие дуалистические доктрины: мессалианство, павликианство, богомилизм. Прозвище „манихей“ превращается в определенном смысле в синоним еретика, если точнее, еретика-дуалиста и переносится на возникнувшие позже неоманихейские учения ${ }^{23}$.

Если, однако, говорить о переводе лексемы „манихей“ с греческого на староболгарский в Шестодневе, надлежит учесть не только позднейшую византийскую ересиологичнескую традицию, но и время создания греческих шестодневов. Образцы Иоанна Экзарха взяты из раннехристианских сочинений, связываемых с именами св. Василия Великого, св. Иоанна Златоуста, Севериана Гавальского (известных староболгарскому автору, естественно,

\footnotetext{
${ }^{19}$ Hexaemeron, III, p. $173-175$, гр.-

${ }^{20}$ Hexaemeron, V, p. 105-107, гр.+

${ }^{21}$ См. здесь, прим. 9; Д. ДРАГОЈЛОвић, Богомилство на Балкану..., vol. II, p. 71-73, 95.

${ }^{22}$ См., например, чин прима еретиков в Церковь в: L’Eucologio Barberini gr. 336, ed. S. PARENTI, E. VelKovska Roma 1995 [= BEL.S, 80], p. 155.

${ }^{23}$ Cf. G. Minczew, Remarks on the Letter of the Patriarch Theophylact to Tsar Peter in the Context of Certain Byzantine and Slavic Anti-Heretic Texts, SCer 3, 2013, p. 113-130.
} 
по позднейшим византийским спискам $)^{24}$. В эпоху Отцов Церкви манихейство, ранние тринитарные и христологические ереси были все еще реальной угрозой для чистоты ортодоксии. Обвинения в крайнем дуализме, извращении христианской догмы и др. адресовались против р е а л н н х манихеев, ариан, савеллиан. Лишь на более позднем этапе, примерно после VI в., лексема „манихей“ начинает обозначать „мессалианин“ („евхит“), „павликианин“, а еще позднее - и „богомил“. Можно допустить, что в переводных частях, где говорится о манихеях, Иоанн Экзарх точно следует образцам, то есть раннехристианским шестодневам, описывающим манихейскую доктрину так, как ее понимали св. Василий или св. Иоанн Златоуст. В оригинальном добавлении упоминание о „скверных манихеях“ скорее всего следует за византийскими образцами, где „манихей“ уже означает - в более общем значении - “еретик-дуалист”. Предположение, что в данном случае речь идет о павликианах, поскольку это учение к тому времени уже запустило корни в Болгарии, остается лишь гипотезой, ведь в других византийских и славянских источниках „манихеями” нарицательно именовались не только павликиане.

В тесной связи с дуалистическим мифом о сотворении следовало бы рассматривать и отношение между Богом, творцом невидимого мира, и демиургом, сатаной - создателем злой материи. В гетеродоксальном Рассказе o сотворении сатана - это не библейский ангел, выпавший из небесного воинства (ср. Ис. 14:12; 14:14), а сын Бога - согласно Шестодневу, еретики не стьдятся называть дьявола старшим сыном: не стыдАты сл динавол глагольжщє стартиша сыны. Как упомянуто выше, на этот фрагмент обращает внимание Й. Иванов, а М. Лос углубленно исследует неоманихейский миф в контексте славяно-византийской ересиологической литературы. В этой связи можно рассматривать еще одну фразу, переведенную на сей раз с греческого:

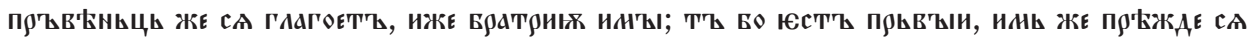

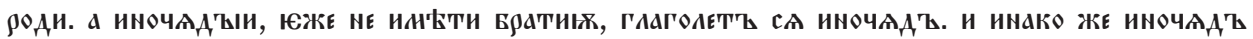

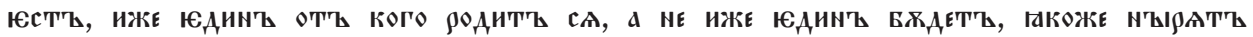
юрєтици. ${ }^{25}$

В ряду более поздних исследований приводятся другие примеры, доказывающие древнее гностическое происхождение этой веры и вариативность отношений Бог - сатана: согласно некоторым источникам, еретики проповедовали, что злой демиург - это старший сын Божий; согласно другим - сатана уступает первородство Иисусу ${ }^{26}$. В трактате Panoplia dogmatica (конец

\footnotetext{
${ }^{24}$ Византийские тексты, использованные в издании Шестоднева см. в: Hexaemeron, I, p. XIIIXIV; Hexaemeron, II, p. V-VI; Hexaemeron, III, p. V-VI; Hexaemeron, IV, p. V-VI; Hexaemeron, V, p. V-VI; Hexaemeron, VI, p. V-VI.

${ }^{25}$ Hexaemeron, V, p. 253, гр.+

${ }^{26}$ Д. ДРАГОЈЛОвИЋ, Богомилство на Балкану..., vol. II, p. 130-131.
} 
XI или само нач. XII вв.), Евфимий Зигавин подтверждает сведение из Шестоднева:

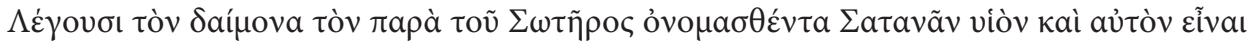

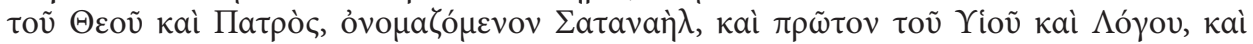

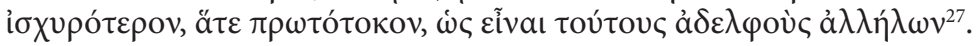

В Беседе против богомилов Пресвитера Козьмы, написанной после Симеоновой эпохи, сатана - это „младший“ сын Бога:

Х н'ЕнАть. и сани и наноноү Прозваша. ${ }^{28}$

B Panoplia dogmatica упоминается и еще одно отклонение, распространенное среди членов богомильской общины в Константинополе, - еретики отождествляли Логос с Архангелом Михаилом:

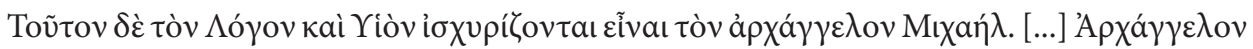

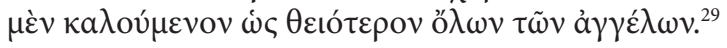

Вера в то, что архангел Михаил - это „второй Бог”, то есть сын Отца, засвидетельствована не только в антиеретической литературе: по-видимому, она была довольно сильной, поскольку ее следы видны и в псевдоканонической литературе. В приписываемом Иоанну Златоусту славянском апокрифическом Слове о том, как Михаил победил Сатанаила, более древняя редакция которого возникла по всей вероятности в XIII в. ${ }^{30}$, архангел Михаил водит космическую битву с демиургом, а после победы восседает одесную Отца, который провозглашает его своим наследником. До настоящего времени не открыт греческий первообраз произведения, независимо от того, что были предприняты попытки доказать его генетическую связь с одним греческим псевдоканоническим словом ${ }^{31}$, где в конце космической ангело-

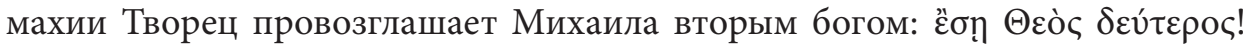
В образе архангела могут быть открыты элементы арианской доктрины -

${ }_{27} P G$, vol. 130, col. 1293. Больше сравнительного материала из византийских памятников см. в: M. Loos, Satan als erstgeborener Gottes...

${ }^{28}$ Цит. по: Ю.К. БегунОв, Козма Пресвитер в славянских литературах, София 1973, p. 331.

${ }^{29} P G$, vol. 130, col. 1301.

${ }^{30}$ А. Милтенова, Апокрифбт за борбата на архангел Михаил със Сатанаил в две редакиии, СЛ 9, 1981, p. 98-113; ЕАDEм, Неизвестна редакиия на апокрифа за борбата на архангел Михаил със Сатанаил, [in:] Литературознание и фолклористика. Сборник в чест на акад. Петър Динеков, София 1983, р. 121-128. Анализ произведения в: Г. Минчев, Един богомилски текст? Слово на св. Йоан Златоуст за това, как Михаил победи Сатанаил, Pbg 34.4, 2010, p. 18-46; G. Minczew, John Chrysostom's Tale on How Michael Vanquished Satanael - a Bogomil text?, SCer 1, 2011, p. 22-52. См. также: Y. Stoyanov, op. cit., p. 264-274.

${ }^{31}$ О. АфиногеновА, Греческий вариант апокрифа о борьбе архангела Михаила и Сатанаила, SeS 3/4, 2006, p. 329-348. 
так, как ее понимали средневековые ересиологи. Божий Сын, по мнению ариан, подчинялся Отцу, был ангелом по природе, исполнявшим поручения своего Отца, и эта вера не была неизвестной в болгарских землях после крещения, поскольку она осуждается в Шестодневе, где видны отголоски споров между ортодоксами и арианами относительно подчиненной Отцу

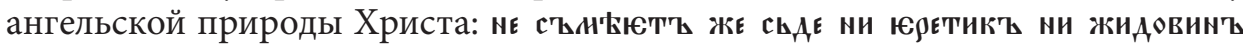

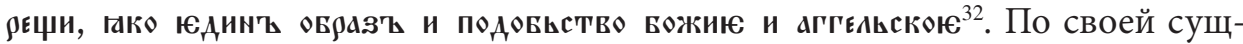
ности последнее обвинение относится скорее к раннехристианским тринитарным ересям, нежели к неоманихейскому дуализму, но так как в данном случае природа Христа имеет прямое отношение к акту сотворения и связанной с ним еретической ангелологии, сведение из Шестоднева может быть отнесено и к дуалистической космогонии и космологии.

\section{2. Тринитарные ереси и дуализм.}

Староболгарский писатель напрямую подчеркивает значение догмы о Св. Троице как основания ортодоксальной веры. В Слове о втором дне за-

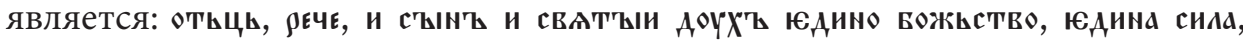
юдино цтсальство ${ }^{33}$. В этом смысле все ереси (в том числе дуалистические) являются своего рода отклонением от установленной в святоотеческом богословии догмы.

В нескольких местах в Шестодневе изобличаются элементы дуалистических доктрин, подчиняющих Сына Отцу. Еретики хуже, чем иудеи и демоны, которые признают Христа Сыном Божьим, а не творением:

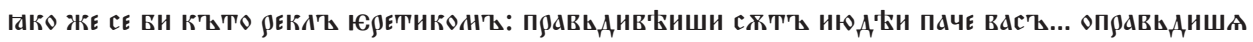

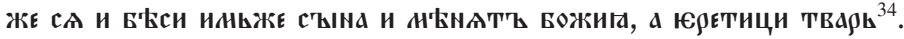

В ином фрагменте, который имеет соответствия в византийских памятниках, указано, что согласно еретикам Сын создан Отцом, а Сын (позднее)

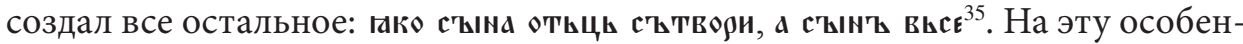
ность еретических учений обращают внимание византийские авторы разных эпох. Одно из ее наиболее точных описаний дает Евфимий Зигавин в Паноплия догматика.

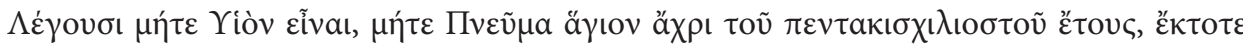

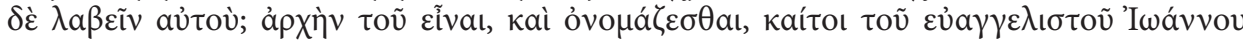

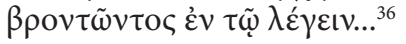

\footnotetext{
${ }^{32}$ Hexaemeron, V, p. 219, гр.+

${ }^{33}$ Hexaemeron, II, p. 57-59, гр.+

${ }^{34}$ Hexaemeron, V, p. 241-243, гр.+

${ }^{35}$ Hexaemeron, IV, p. 409-411, гр.+

${ }^{36} P G$, vol. 130, col. 1293.
} 
В предыдущем абзаце того же произведения отмечено, что согласно константинопольским богомилам, Сын и Св. Дух рождены 5000 лет спустя после Отца. Латинский переводчик сначала исправляет „ошибку“в греческом тек$\mathrm{cte}^{37}$, прибавляя 500 лет, после чего прибавляет еще 33 года - таким образом, согласно параллельному латинскому переводу, Сын и Св. Дух созданы в 5533 году до Рождества. На первый взгляд кажется, что греческий текст неправильно понят переводчиком. Год 5500, однако, появляется неслучайно в богомильских верованиях. Согласно византийскому летоисчислению, сотворение мира имело место 5500 лет перед Воплощением Слова. Иначе говоря, согласно неоманихейским учениям, Сын и Св. Дух не существуют извечно, а „появляются“ едва лишь в начале акта сотворения. Отец как бы „передает свои полномочия“ своему старшему/младшему Сыну, удаляется в плерому и ему оставляет заботы о создании презренной материи. Иоанну Экзарху понятно, что если Сын неизвечен и неравен Отцу, то Он для неоманихеев превращается в демиурга, в „первородного сына“, отождествляемого еретиками с сатаной. Таким образом ересиологическая концепция, отраженная в византийских шестодневах и дополненная в произведении староболгарского автора, получает завершенный вид: дуалистический миф о творении как деле демиурга напрямую связан с отклонениями от догмы о Св. Троице. В нескольких местах в староболгарском тексте Шестоднева упоминаются тринитарные ереси; в большинстве случаев эти фрагменты - переводы с греческого и в некоторых из них еретики непосредственно названы: ариане, савеллиане, несториане. В тексте защищается вера, что всякое рассуждение

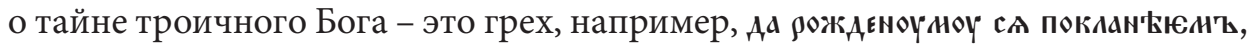

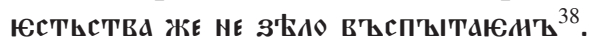

Ариане и несториане не понимают своего собственного естества,

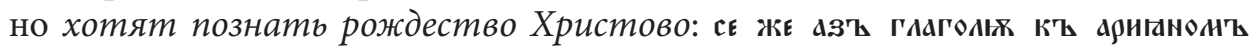

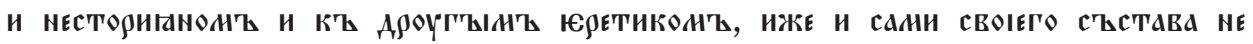

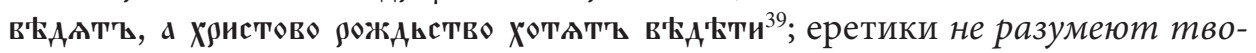

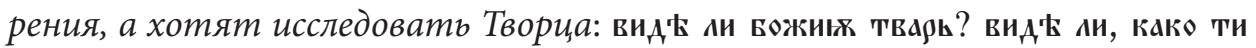

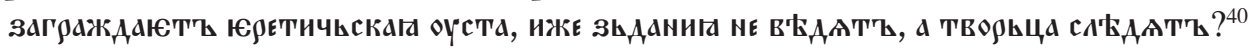
К обвинениям в субординации стоит отнести также упомянутый выше фрагмент, осуждающий арианские взгляды на ангельскую природу Христа.

Упоминание о несторианах рядом с арианами неслучайно: независимо от того, что ересь Нестория не является тринитарной sensu stricto, она относится к тайне Воплощения и к роли Богородицы в нем. Неоманихеи умаляли роль Богоматери в сакральной истории. Согласно Тайной книге, она, подобно Сыну, является ангелом, посланным на землю Богом, чтобы „принять”

\footnotetext{
${ }^{37}$ Ibidem, col. 1294.

${ }^{38}$ Hexaemeron, V, p. 189, гp.+

${ }^{39}$ Hexaemeron, I, p. 119-121, гр.-

${ }^{40}$ Hexaemeron, IV, p. 452-453, гр.+
} 
Христа $^{41}$. Иисус сошел с неба, вошел через ее одно ухо и вышел через другое - еретический взгляд, который должен был быть хорошо известен современным Иоанну Экзарху византийским ересиологам. В Послании патриарха Феофилакта иарю Петру мы читаем:

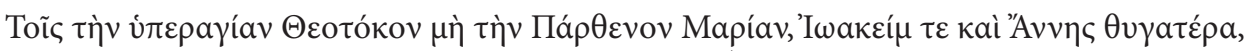

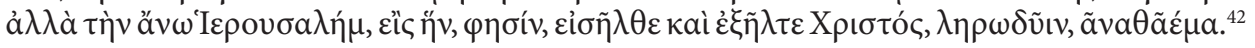

Эта вера, которая воспринималась как особенно противная защитниками ортодоксии, повторяется и в других более поздних византийских и славянских источниках ${ }^{43}$.

К этим переводным фрагментам необходимо добавить оригинальный текст Иоанна Экзарха, где прямо заявляется, что еретическое пустословие противно решениям первых четырех Вселенских соборов: чєттыри съьөюи дриюви и савєлови и накєдонитаньсции ${ }^{44}$. Интересна в данном случае параллель между этим кратким текстом и возникшей значительно позже Беседой против богомилов (об этом речь пойдет ниже). В предисловии к Беседе подобным образом перечисляются тринитарные ереси: дьявол сначала вошел в Ария, потом в Савеллия и Македония. Все три ересиарха были осуждены Отцами I Никейского собора в 325 г. ${ }^{45}$

\footnotetext{
${ }^{41}$ И. ИВАНОВ, op. cit., p. 82: Cum cogitaret Pater meusmittere meinmundum, misit angelum suum ante me, nomine Maria, ut acciperet me. Ego autem descendens intravi per auditum et exivi per auditum.

${ }^{42}$ Цит. по: I. Dujčev, L'epistola sui Bogomili del patriarcha Teofilatto, [in:] IDEM, Medioevo bizantinoslavo, vol. I, Roma 1965, p. 313-314. J. Gouillard и Д. Драгојловић доказывают, что эти анафемы восходят ко второй редакции т.н. „краткой формулы“ в Истории Петра Сицилийского, см.: ТМ 4, 1970, p. 186-187; Д. ДРАголЛОВИЋ, Богомилство на Балкану и у Малој Азији. I. Богомилски родоначалници, Београд 1974, p. 131. См. также: G. Minczew, Remarks on the Letter of the Patriarch Theophylact..., p. 123.

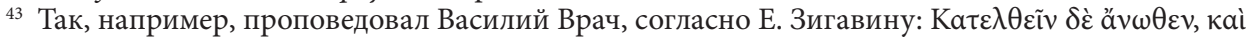

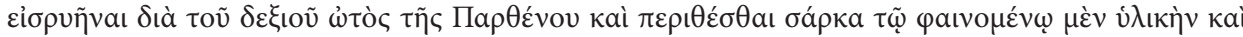

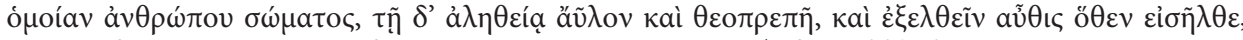

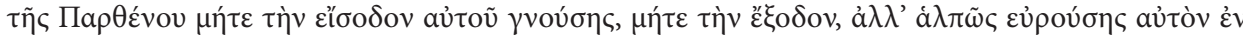

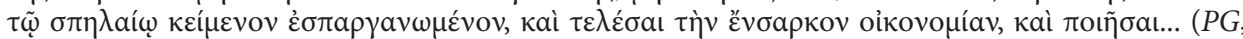
t. 130, col. 1301). В Беседе против богомилов Пресвитер Козьма не указывает, в чем точно богомилы искажают культ Богородицы, но по всей вероятности он имел в виду подобные отклонения, так как в части, посвященной Матери Божьей, он заявляет, что не собирается

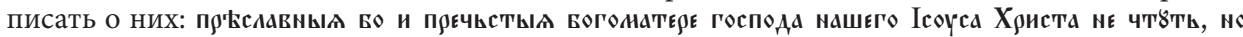

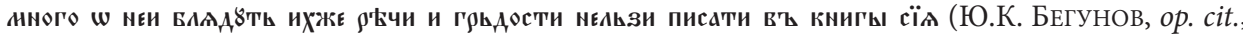
p. 320-321). Больше о Богородице в верованиях неоманихеев см. например в: S. Runciman, op. cit., p. $77-78$.

${ }^{44}$ Hexaemeron, VI, p. $15-17$, гр. -

${ }^{45}$ Ю.К. БЕГУНОВ, op. cit., p. 298-299.
} 


\section{3. Дуалисты и православная литургия.}

Несколько переведенных с греческого фрагментов заслуживает особого внимания, так как они имеют связь с известным большинству византийских и славянских ересиологов отрицательным отношением к официальному церковному ритуалу, характерным для последователей средневековых неоманихейских учений ${ }^{46}$. В Слове о втором дне отмечено:

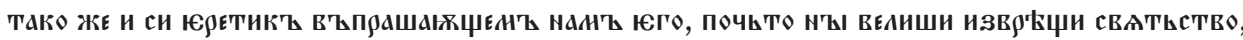

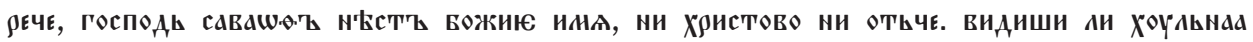

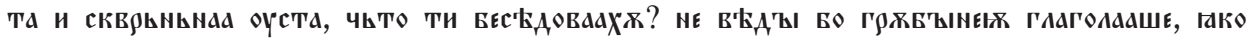

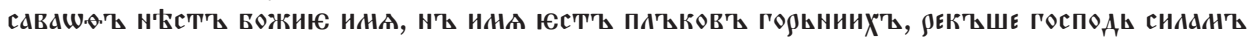

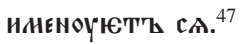

На первый взгляд этот фрагмент относится скорее к дуалистическому мифу о сотворении и связанному с этим негативному отношению неоманихеев к ветхозаветному канону. Еретики утверждали, что Господь Саваоф не является ни именем Христа, ни именем Отца; они унаследовали из гностицизма и некоторых раннехристианских гетеродоксных учений негативное отношение к ветхозаветному Ягве/Саваофу - творцу Вселенной. По их мнению, именно он является демиургом, создателем материального мира, противником „невидимого“ гностического бога. Наиболее полную реализацию эта концепция находит в доктрине ересиарха Маркиона (ок. 100 - после 160 гг.), где Бог Закона противопоставляется Спасителю, доброму и „непознаваемому“ Богу, обитающему на небесах над более низким Ягве. Спаситель выслал в мир свой дух (Иисуса Христа), чтобы противопоставить мрачному учению Ягве Евангелие любви. Следовательно, согласно Маркиону, Новый завет - это не продолжение Ветхого, а его отрицание ${ }^{48}$.

Ортодоксальная доктрина, однако, четко разграничивает значения Божьих имен, поэтому в Шестодневе высмеивается „грубость“ еретика, который не знает, что Саваоф - это имя господина небесных сил. Согласно византийским и славянским ересиологам, дуалисты отрицали все или большинство ветхозаветных книг. Пресвитер Козьма отмечает:

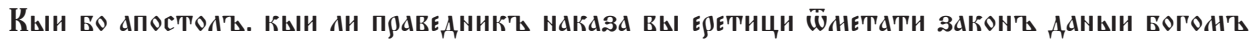

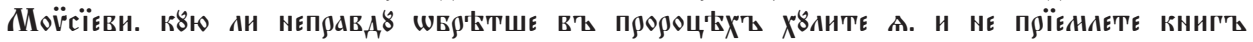
писаныих'ъ ини. ${ }^{49}$

\footnotetext{
${ }^{46}$ Хорошее представление источников, в которых упоминается об отрицательном отношении еретиков к православному ритуалу, см. в: Д. ДРАГолЛОвић, Богомилство на Балкану..., II, p. $123-127$.

${ }^{47}$ Hexaemeron, II, p. 63, гр.+

${ }^{48}$ Подробнее о Маркионе см. в: К. Rudolph, op. cit., p. 275-279; S. Runciman, op. cit., p. 8-11.

${ }^{49}$ Ю.К. БЕГУНОВ, op. cit., p. 318.
} 
В анафемах, прилагаемых к ряду церковно-юридических памятников, также осуждаются отрицавшие библейский канон еретики ${ }^{50}$.

Шестоднев описывает подобные еретические заблуждения. Ортодоксальное учение защищается с помощью авторитета пророков, то есть авто-

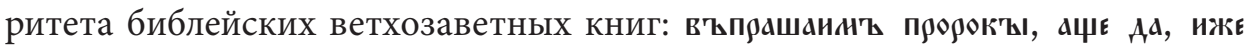

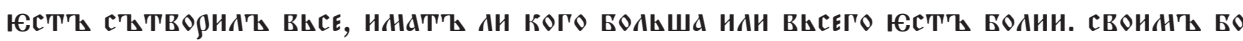

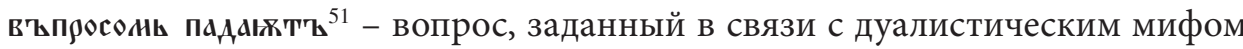
о сотворении. Немного далее в этом же Слове о четвертом дне упоминается, что пророки величают дела искусного Творца, а еретики их принижают.

В начале цитаты отмечено, что еретики требовали от православных христиан отречься от ангельской песни: почьто ны вєлиши изв то есть от Трисвятого (Sanctus, Trisagion), древнего гимна по Ис. 6:3 и в то же время важного элемента Литургии Верных, где ангельские чины воспевают Господина небесных сил именем „Саваоф“.

Приведенная выше цитата должна рассматриваться в более широком контексте греческих шестодневов и их староболгарского перевода/компиляции. Далее, в Слове о втором дне, опять в связи с Трисвятым, упоми-

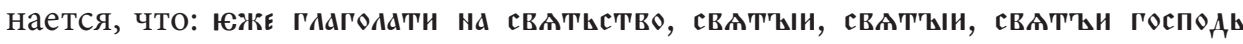

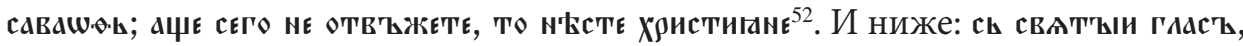

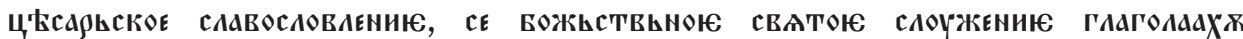

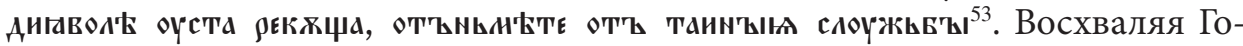
спода Саваофа, ангелы в сущности восхваляют Христа; Саваоф, согласно защитникам ортодоксии - это прообраз Спасителя и в то же время - первое лицо нераздельной Св. Троицы. Следовательно, без Tрисвятого (Trisagion) преосуществление Даров невозможно, то есть Христова жертва недействительна. Логическим следствием отрицания Трисвятого в Литургии верных является впадение в ересь.

Приведенные фрагменты показывают еще один аспект неоманихейских учений, о котором упоминают почти все антиеретические сочинения славяно-византийской ойкумены, а также анафемы в синодиках и др. церковноюридических и литургических памятниках: отрицательное отношение неоманихеев к православной литургии ${ }^{54}$.

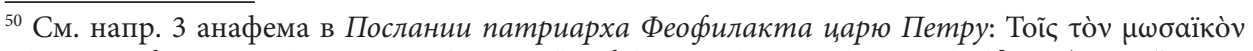
vó cit., p. 313). Аналогичным образом в Бориловом синодике (Борилов Синодик. Издание и превод, ed. et trans.: Ив. БОЖИЛОв, А. ТотОМАНОВА, Ив. БИЛяРСКИ, София 2010, p. 123).

${ }^{51}$ Hexaemeron, II, p. 63, гр.+

${ }^{52}$ Hexaemeron, II, p. 59, гр.+

${ }^{53}$ Hexaemeron, II, p. 87-88, гр.+

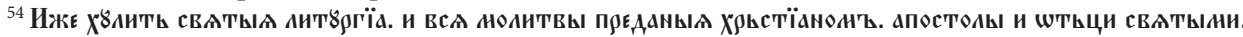

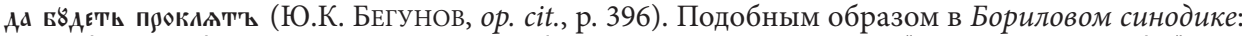

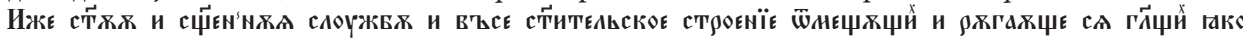

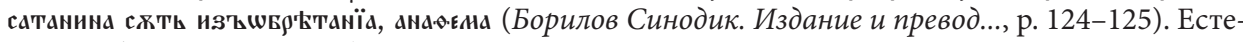
ствено, большинство анафем в славянских памятниках - перевод с греческого.
} 
Логичным следствием еретического презрения к ветхозаветному Богу Закона является нежелание, чтобы Он упоминался как „Саваоф” в Трисвятом. Сведение из греческих шестодневов, переведенное Иоанном Экзархом, отнесенное к конк рет н о у эл е ме н т у православной литургии, имеет исключительную ценность, так как оно подтверждено лишь в одном более позднем антиеретическом трактате: Послании Евфимия из Перивлепты (Акмонии) середины XI в. Греческий монах обвиняет богомилов из Малой Азии и Константинополя в том, что они отрицали Трисвятое, возглашение Слава Отиу и Сьну... и Господи помилуй ${ }^{55}$, то есть не всю литургию, а ее элементы, противоречащие их дуалистической визии мира: Трисвятое, которое для них было гимном ветхозаветному Саваофу; Слава Отиу и Съну..., потому что провозглашает догму о Св. Троице; Господи помилуй, поскольку по их мнению воспеваемый в литургии Господь - это злой демиург, а не дающий прощение Бог.

Возможно, что эти сведения в Шестодневе - отголосок старых христологических споров в Восточной Церкви. В Хронике Марцелина Комеса в записях о 512 г. отмечено, что в Константинополе на воскресной литургии сторонники монофизитства пели Trisagion, добавляя четвертый элемент к гимну: in hymnum trinitatis deipassianorum quaternitas additur ${ }^{56}$. Согласно П. Харанису, этот акт состоялся в храме Св. Софии и вызвал беспокойства во всем городе, тем более что на следующий день монофизиты пытались повторить Trisagion с четвертой добавкой в церкви Св. Феодора. Дополнение

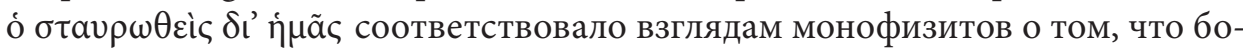
жественную природу Христа поглотила человеческая ${ }^{57}$.

Большинство исследователей неоманихейства приводит примеры, где говорится о тотальном отрицании православного ритуала еретиками; они считали его делом людей, а не Бога, завещавшего апостолам только молитву Отче наш. Особенно ненавистным для богомилов был св. Иоанн Златоуст, почитаемый Церковью как боговдохновенный автор литургии и отрицаемый богомилами, которые его называли „грязноустым“58.

В сравнении со сведениями из посланий Евфимия из Перивлепта и другими данными из ранневизантийской истории, тексты из Шестоднева свиде-

\footnotetext{
${ }_{55}$ G. Ficker, Die Phundagiagiten. Ein Beitrag zur Ketzergeschichte des Mittelalters, Leipzig 1908, p. 33, 7-12; см. также: Д. ДРАГолЛовић, Богомилство на Балкану..., vol. II, p. 125.

${ }_{56}$ Цит. по: Comes Marcellinus, The Chronicle of Marcellinus: a translation and commentary, ed. B. Croke, Тн. Mommsen, Sydney 1995.

${ }^{57}$ P. Charanis, Church and State in the Later Roman Empire. The Religious Policy of Anastasius the First, Thessaloniki 1974, p. 48-50; см. также: M.B. Leszka, M.J. LeszKa, Zarys dziejów Konstantynopola $w$ latach 337-602, [in:] Konstantynopol - Nowy Rzym. Miasto i ludzie w okresie wczesnobizantyńskim, ed. M.J. LeszKa, T. WolińsKa, Warszawa 2011, p. 83.

58 Д. ДРАГОЈЛОвИћ, Богомилство на Балкану..., vol. II, p. 124. Козьма Пресвитер пишет: Ти

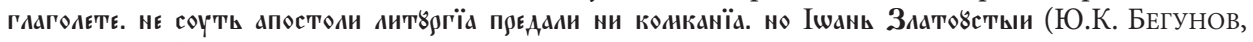
op. cit., p. 313).
} 
тельствуют об одном более детальном отношении приверженцев дуализма к православному ритуалу. Известно, что еретики скрывали свою принадлежность к гетеродоксным общинам; прикидываясь ортодоксальными христианами, они принимали участие в Св. Литургии. Можно предположить, что те из них, кто участвовал по принуждению в санкционируемом Церковью официальном культе, «замалчивали» неудобные для неоманихейских учений литургические тексты: в данном случае упоминание имени ветхозаветного Саваофа.

\section{4. Языческий солярный культ и манихейский дуализм.}

В начале настоящего исследования упоминалось значение статьи М. Лоса для изучения остатков языческих и дуалистических (манихейских) верований в солнце как в изначально существовавшее божество. В Слове о четвертом дне староболгарской автор проклинает язычников-славян и манихе-

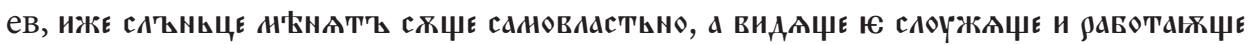

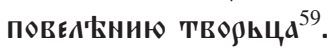

Чешский медиевист не обратил внимание на еще одно оригинальное староболгарское дополнение ко греческому тексту в этом же Слове, где подобным образом изобличаются верования манихеев:

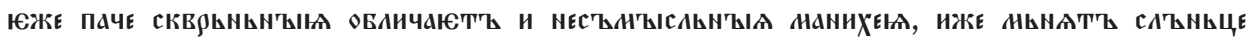

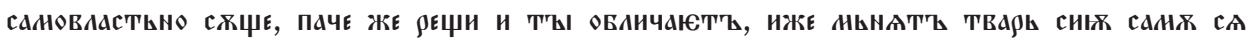

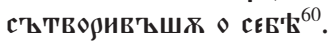

В этих двух оригинальных фрагментах Иоанн Экзарх изобличает распространенный в средневековой Болгарии языческий, противоречащий христианской вере солярный культ в такой последовательности: сначала связывает его с манихейством, а далее расширяет влияние «манихейской веры» также на славянские языческие верования, подчеркивая ортодоксальную концепцию сотворения, согласно которой небесные тела не являются «самовластными», а созданными Богом для того, чтобы Ему служить.

Исследованию рудиментов языческих культов в I Болгарском царстве посвящено множество работ, в большинстве которых солярный культ рассматривается как характерный прежде всего для протоболгарской религиозной системы и часто увязывается с проникнувшими с Востока верованиями ${ }^{61}$. Реакцией на такое одностороннее толкование была статья Ивана

\footnotetext{
${ }^{59}$ Hexaemeron, IV, p. 146.

${ }^{60}$ Hexaemeron, IV, p. 41-43, гр.-

${ }^{61} \mathrm{O}$ религиозном синкретизме болгарского государства до и непосредственно после крещения см., например: Y. SтоYAnov, op. cit., p. 139-145. По мнению Бернарда Хамильтона, протоболгары внесли на Балканы иранский зурванизм с характерным для него умеренным дуализмом:
} 
Дуйчева 1950 г. ${ }^{62}$, где на базе сравнительного анализа Ответов папь Николая болгарам и некоторых славянских и греческих источников убедительно доказывается, что не только солярный, но и лунарный культ был характерен как для протоболгарской религии, так и для заселявших болгарские земли славянских племен. На этот факт в сущности обращают внимание и предыдущие исследователи болгарских древностей ${ }^{63}$.

И. Дуйчев приводит достаточно убедительные примеры из сочинений византийских авторов и из средневековых славянских текстов, в которых говорится о почитании в качестве богов солнца, луны и звезд: такие сведения встречаются, например, у Феофилакта Охридского и в одном славянском слове, приписываемом св. Иоанну Златоусту ${ }^{64}$. В апокрифическом Хождении Богородицы по мукам языческие культы среди славян не только перечисляются, но и изобличаются с помощью схожей с Шестодневом богословской аргументации, относящейся к акту сотворения: солнце, луна, звезды, земля и животные - это творения Бога, а всяка другая вера - языческая:

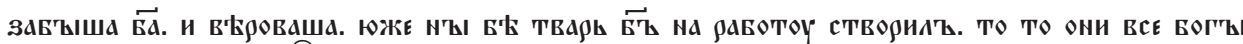

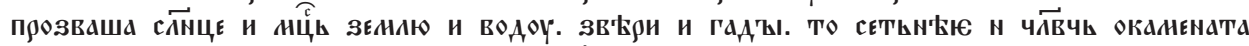

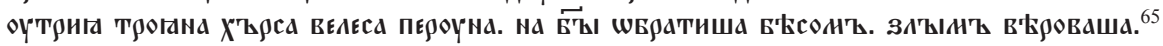

Эти два фрагмента из Шестоднева заслуживают особого внимания по крайней мере по трем причинам.

Первое оригинальное добавление Иоанна Экзарха - это в сущности отголосок византийских ересиологических текстов, обвинявших последователей Мани в идолопоклонстве: идеологическая манипуляция, которая не находит подтверждения в подлинных источниках по этой дуалистической религии. Манихеи не считали солнце «самовластным», но были край-

B. Hamilton, The Cathars and Seven Churches in Asia, [in:] Byzantium and the West c. $850-$ c. 1200. Proceedings of the XVIII Spring Symposium of Byzantine Studies. Oxford, Amsterdam 1988, p. 284-290. См. также: Д. АНГЕЛОв, Богомилството..., p. 105-118 и бел. 16.

${ }^{62}$ И. Дуйчев, Славяно-болгарские древности IX в., BS 11.1, 1950, p. 6-31. Автор не вспоминает о сведениях из Шестоднева. Среди более старых исследований внимания заслуживает работа Ю. ТрифоновА, Сведения за старобългарския живот от „Шестоднева“ на Йоан Екзарх, СБАН 35/19, 1926, p. 1-26.

${ }^{63}$ Й. ИваНОВ, Культ Перуна у южных славян, СОРЯС 8.4, 1904, p. 140-174. Это исследование до сегодняшнего дня является одной из наиболее серьезных попыток проанализировать солярный культ среди балканских славян. Из более новых работ на тему общеславянского измерения культа Перуна см.: В.В. ИвАНОВ, В.Н. ТоПоРОВ, Исследования в области славянских древностей. Лексические и фразеологические вопросы реконструкиии текста, Москва 1974, p. 4-30. См. также статью Перун этих же авторов в: Славенска митология. Енциклопедијски речник, Београд 2001, p. 422-423.

${ }^{64}$ И. Дуйчев, Славяно-болгарские древности..., p. 11-12.

${ }^{65}$ Цит. по: Хождение Богородищы по мукам, [in:] Н.С. Тихонравов, Памятники отреченной русской литературы, vol. II, Москва 1863, p. 31. См. также: И. Дуйчев, Славяно-болгарские древности..., p. 12. 
не привязаны к символике света; радикальный космогонический дуализм строился на базе антитезиса «Царство света» - «Царство мрака». Царство света - это обитель Бога, который и является богом света, а Царство мрака - обитель злых архонтов. Часто повторяющиеся образы «Царства света», «бога света» должны были отождествляться противниками манихейства с его носителем, то есть с солнцем - отсюда позднейшие обвинения манихеев в идолопоклонстве, в котором небесное светило уже не является атрибутом бога, а «самосоздавшимся» богом. Эта интерпретация, известная староболгарскому писателю вероятно из других византийских текстов, находит отражение во приведенных фрагментах.

Тексты ставят еще один важный вопрос: о путях проникновения этих еретических представлений в болгарские земли до и после крещения. Не отрицая значения Востока, откуда подобные крайне дуалистические доктрины с элементами солярного культа могли проникнуть на Балканы через протоболгарскую религиозную систему, не стоит забывать о византийском влиянии. Довольно интересный пример, связанный с эпохой непосредственно до крещения болгар во второй половине IX в., открываем в Житии патриарха Игнатия. Некий Феодор (Theodoros Santabarenos), живший во времена патриарха Фотия, был известен в столице как предсказатель будущего, но в действительности занимался магией. Согласно иному тексту этого же времени, отец Феодора был колдуном и манихеем. Чтобы избежать преследований, он убежал к болгарам еще до их крещения и там отрекся от христианства $^{66}$. Конечно, открытым остается вопрос, насколько отец Феодора был манихеем или скорее адептом оккультических учений и/или неоманихейских взглядов, вынужденным искать убежища в еще нехристианской Болгарии. Важнее в данном случае однако то, что дуалистические представления с элементами солярного культа проникают из Византии в Болгарию, где распространяются вместе с языческими гадательными практиками. Наверняка они должны были быть популярными, раз Иоанн Экзарх два раза демонстрирует свое личное отношение к этим отклонениям от христианского учения.

Связывание манихейского «язычества» со славянскими верованиями в бога-солнце также заслуживает особого внимания и должно рассматриваться не только в качестве свидетельства наличия солярного культа в религиозных системах славян и протоболгар - этот вопрос достаточно подробно анализируется в цитируемой выше литературе. Рассматриваемый в более широком контексте соответствующий фрагмент посвященного сотворению

${ }^{66}$ Cf.: P. Magdalino, Occult Science and Imperial Power in Byzantine History and Historiography ( $9^{\text {th }}-12^{\text {th }}$ Centuries), [in:] P. Magdalino, M. Mavroudi, The Occult Sciences in Byzantium, Geneva 2006, p. 131 с указанными там источниками. Об астрономических и астрологических знаниях среди балканских славян и их связи с шестодневами см.: Цв. КрИСТАНОв, И. ДуйчЕв, Ecmemвознанието в средновековна България, София 1954; Ц. ЧоловА, Естественонаучните знания в средновековна България, София 1988. 
небесных светил (по Быт. 1: 14-18) Слова о четвертом дне - это в то же время изобличение унаследованного из языческой древности астрологического знания и связанных с ним гадательных практик и оккультных учений. Во многих местах Слова подчеркивается связь веры в «божественность» небесных тел с отрицаемыми Церковью «тайными учениями» - астрологией и магией. Например, в нескольких оригинальных фразах, расположенных непосредственно после цитируемых выше фрагментов, говорится, что неверно проповедуют те, кто утверждает, что солнце, луна и звезды самовластны.

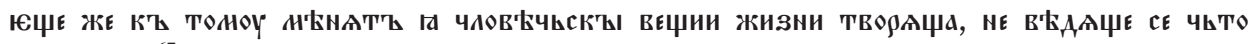
БААА ХџЕ... ${ }^{67}$

ни чАов'Чьск' жизнии ножета ст

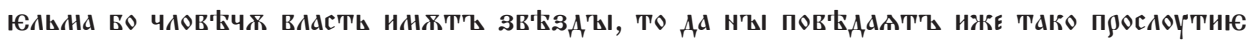

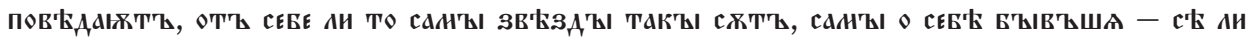

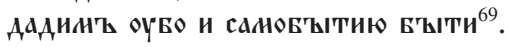

Свои непосредственные наблюдения на тему религиозной жизни в I Болгарском царстве Иоанн Экзарх отражает в двух оригинальных добавлениях ко греческому переводу Шестоднева, которые дополняет своими рассуждениями о влиянии небесных тел на человеческую судьбу. Староболгарский автор усматривал со стороны неоманихейских верований угрозу для неокрепшей еще христианской веры новокрещенных болгар. Не ускользнули от его внимания также остатки славянского языческого солярного культа. Он логично связал два религиозных феномена, интерпретируя их в духе ортодоксальной догматики:

- Небесные тела не могут существовать сами, они являются творением Бога. Утверждение о «божественности» солнца и небесных тел противоречит библейскому рассказу о сотворении и представляет собой дуалистическое, «манихейское» - согласно Иоанну Экзарху - отклонение от церковной догмы.

- Библейский рассказ о сотворении опровергает унаследованные из античности астрологические знания и гадательные практики. Солнце, луна и звезды не имеют власти над человеческой судьбой, поэтому астрология должны быть изгнана из христианской веры.

\footnotetext{
${ }^{67}$ Hexaemeron, IV, p. 127 , гр.-

${ }^{68}$ Hexaemeron, IV, p. 127-129, гр.-

${ }^{69}$ Hexaemeron, IV, p. 135 , гр.-
} 


\section{5. Шестоднев Иоанна Экзарха и Беседа против богомилов Пресвитера Козьмы.}

В ряду исследований на тему Беседы против богомилов анализируются греческие и славянские источники, которые использовал Пресвитер Козьма при составлении текста. Наиболее углубленные - статьи Михаила Г. Попруженко ${ }^{70}$ и Анре Вайяна ${ }^{71}$; кроме них подробно на этом вопросе останавливается и Юрий К. Бегунов ${ }^{72}$. В случае цитат из греческих произведений Отцов Церкви, житийных текстов, церковно-юридических, литургических и даже апокрифических памятников появляется вопрос, который не имеет однозначного решения в научной литературе: переводил ли Козьма с греческого или скорее знал уже переведенные на староболгарский сочинения византийских авторов? Например, А. Вайян утверждает, что часто встречаемые

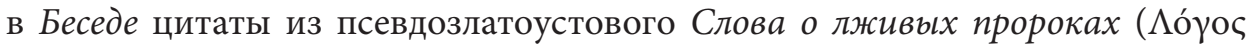
$\pi \varepsilon \rho \grave{~} \psi \varepsilon v \delta о \pi \rho о \varphi \eta \tau \tilde{\omega} v)$ - это перевод с греческого ${ }^{73}$. Ю.К. Бегунов однако убедительно доказывает, что по всей вероятности болгарский пресвитер использовал славянский перевод Слова, возникший в эпоху Симеона и сохранившийся в так называемом Симеоновом Златоструе ${ }^{74}$. Схожая проблема наблюдается и в случае с цитированием приписываемого в Беседе против богомилов св. Василию Великому произведения, являющегося в сущности фрагментом из Богословия св. Иоанна Дамаскина ${ }^{75}$. По мнению Ивана Гошева, речь идет о пересказе XIII главы Богословия ${ }^{76}$, но опять-таки Ю.К. Бегунов доказывает, что в данном случае речь идет об использовании уже переведенного в эпоху Симеона текста - и переведенного не кем-либо, а тем же Иоанном Экзархом, под заглавием Небеса ${ }^{77}$.

Сравнительные исследования лексического состава обоих произведений подтверждают близость между ними. Анализируя некоторые редкие слова в Шестодневе, Слове о Преображении, Похвале Иоанна Богослова Иоанна Экзарха и в Беседе против богомилов, Ангел Давидов приходит к выводу, что лексиката на Йоан Екзарх Български споделя редица особености

\footnotetext{
${ }^{70}$ М.Г. ПоПруженкО, Козма Пресвитер - болгарский писатель Х века, София 1936 [= БС, 12], p. CXLIII-CCV.

${ }_{71}^{7}$ A. Vaillant, H. Puech, Le traité contre les Bogomiles du prêtre Cosmas, Paris 1945 [= TPIES, 21], p. $45-52$.

${ }_{72}$ Ю.К. БЕГУНОВ, op. cit., p. 221-249.

${ }^{73}$ A. Vaillant, H. Puech, op. cit., p. 47-50.

${ }^{74}$ Ю.К. БЕГУНОВ, оp. cit., p. 221-230.

${ }^{75}$ A. Vaillant, H. Puech, op. cit., p. 50-51.

${ }^{76}$ И. ГОшев, Старобългарската литургия според български и византийски извори от IX-X в., ГСУ.БФ 6 (fasc. 8), 1932, p. 60-64.

77 Ю.К. БЕгунов, ор. cit., р. 232: Следует допустить, что Козма Пресвитер знал „Книги богословия" знаменитого византийского теолога, тем более, что, благодаря Иоанну Экзарху, они были хорочо известны в Болгарии.
} 
с лексиката на Презвитер Козма ${ }^{78}$, а оба произведения связаны с литературной продукцией Преславской школы.

Чтение - даже не параллельное - фрагментов Шестоднева, в которых речь идет о всяческих еретиках, и Беседы против богомилов производит впечатление их определенной близости, родственности. Подозрение, что Козьма мог знать (хотя и не цитировать напрямую) трактат Иоанна Экзарха, усиливает относительно недолгий отрезок времени, отделяющий появление этих двух текстов, а также высокий авторитет Шестоднева. Произведения представляют собой различные жанры, различна также их функция и стилистика. Тем не менее, в обоих элементы учений, определяемых как «еретические», являются важным (а в Беседе даже основным) центром полемических высказываний.

В первой, полемической, части Беседь, Пресвитер Козьма в различных контекстах упоминает еретиков более 60 раз $^{79}$. Список упоминаний существительного еретик для Шестоднева намного скромнее и составляет 36 единиц (причем прилагательное еретический появляется только 6 раз).

Иоанн использует определение еретик «нейтральным» образом (для названия иноверца, без дополнительной маркировки) и пишет, в том чи-

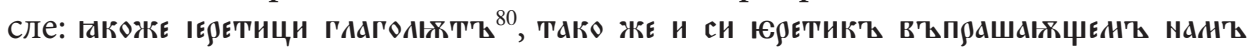

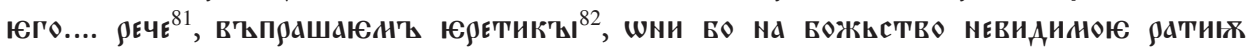

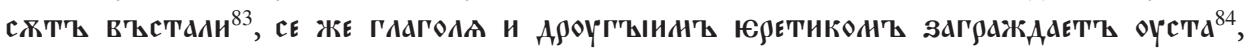

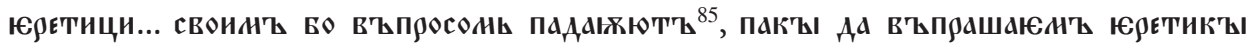

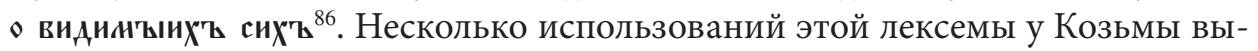
глядит похоже: в формулировках типа еретики утверждают, вопрошаем

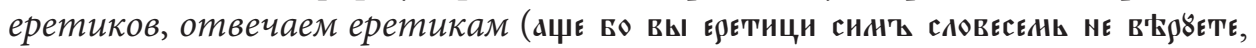

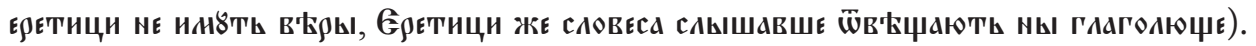

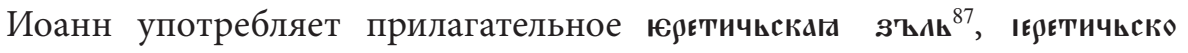
извдачєниєе ${ }^{88}$, так же, как и Козьма ${ }^{89}:$ еретическое учение, еретический рас-

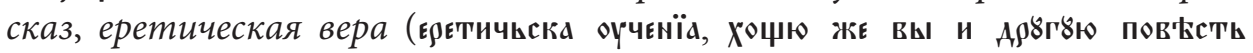

\footnotetext{
${ }_{78}$ А. ДАвидов, Някои лексикални успоредици между Йоан Екзарх и Презвитер Козма, [in:] ПКШ, vol. I, 1999, р. 295.

${ }^{79}$ Во всем тексте лексема „еретикъ” появляется 66 раз, см. А. ДАвидов, Речник-индекс на Презвитер Козма, София 1976, р. 98.

${ }^{80}$ Hexaemeron, I, p. 211, гр.-

${ }^{81}$ Hexaemeron, II, p. 63, гр.+

${ }^{82}$ Hexaemeron, IV, p. 362, гр.+

${ }^{83}$ Hexaemeron, V, p. 219, гр.+

${ }^{84}$ Hexaemeron, I, p. 53, гр.-

${ }^{85}$ Hexaemeron, IV, p. 411, гр.+

${ }^{86}$ Hexaemeron, IV, p. 362, гр. +

${ }^{87}$ Hexaemeron, IV, p. 457, гр.+

${ }^{88}$ Hexaemeron, I, p. 107-109, gr.+

${ }^{89}$ Цитаты из Беседь приводятся не по изданию Ю. Бегунова, а на основе подготавливаемого в настоящем времени в Лодзинском университете нового издания этого произведения.
} 


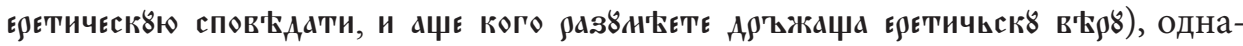
ко несколько раз Козьма дополнительно маркирует эту лексему, используя ее для определения лжи, вранья и лицемерия (лєсть єрєтичьска, б̈ прєльсти є९єтичьскы, Ажїи пюољоци. ९єкшє є९єтици). Еретиков НаЗЫвает тщцеславными,

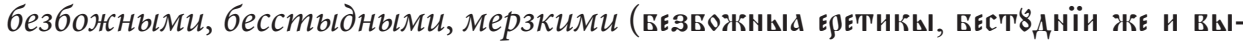

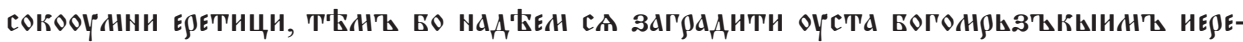

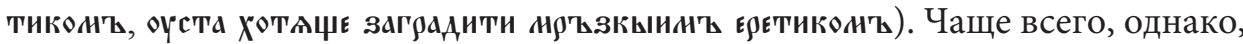
еретики у Козьмы являются подлежащим предложения, в котором сказуемое выражается глаголом «врать», «лгать», «быть неправдивым» (єяєтици

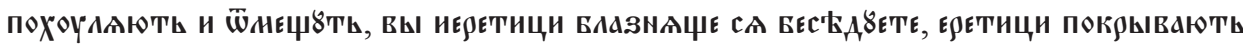

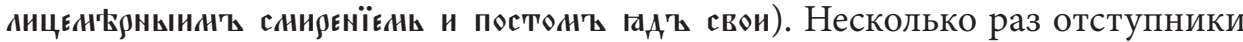
называются с использованием не особо элегантных сравнений (скөљћє во ско-

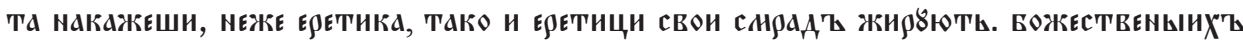

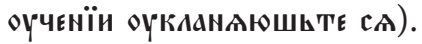

Характерным элементом трактата Козьмы является - оправданное и допустимое в полемическом жанре - употребление вопросов (зачастую риторических), в которых автор сопоставляет провозглашаемые еретиками учения с позицией официальной Церкви. Отсюда использование существительного еретик в звательном падеже единственного и множественного

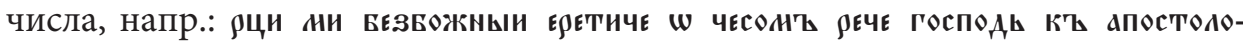

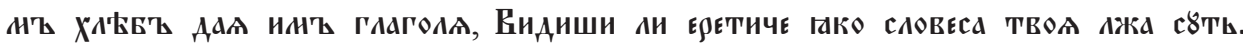

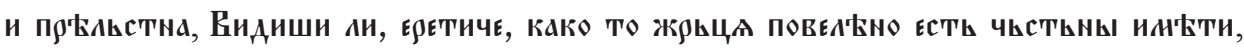

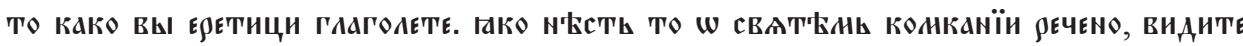
АИ Е९ЕТИЦИ. ГаКО ПЮО९ОЦИ И СЕАТИ СУТТ, ТО ОУЖЕ ПОСАУШАИТЕ Е९ЕТИЦИ АЩЕ ИНАТЕ

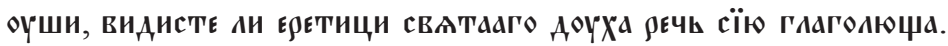

В Шестодневе риторических вопросов к гетеродоксам относительно немного. Иоанн Экзарх не вступает в (вероятно ненужную с его точки зрения) дискуссию с еретиками, искажающими мировой порядок. Ставит, по правде, вопросы на тему их убеждений, но направляет их, скорее, к правоверным, чтобы они сами могли сделать оценку. В конкретных фрагментах они выглядят так:

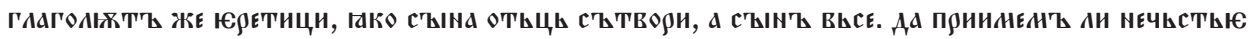
To? ${ }^{90}$;

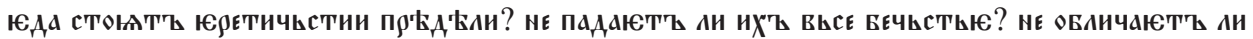

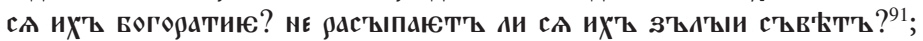

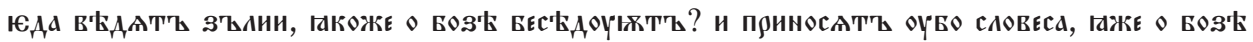

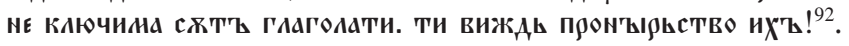

\footnotetext{
${ }^{90}$ Hexaemeron, IV, p. 409-411, гр.+

${ }^{91}$ Hexaemeron, IV, p. 419, гр. +

${ }^{92}$ Hexaemeron, V, p. 175 , гр.+
} 
Интересен также вопрос, видно ли и если да, то насколько - на фоне показанных выше лексических сходствий - у обоих авторов совпадение содержания и формы, что по сути может быть вопросом о наличии у Козьмы цитат/парафраз из произведения Иоанна. В составленном списке "редко используемых» лексем, общих для обоих трактатов, А. Давидов помещает 26 единиц ${ }^{93}$. Однако, независимо от схожести лексем, стоит поискать совпадений и на макроуровне: фраз/предложений, либо даже более обширных фрагментов. Существует формулировка, которая в обоих произведениях выглядит идентично, причем в обоих появляется больше чем один раз.

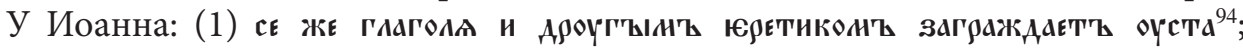

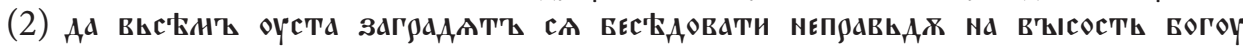

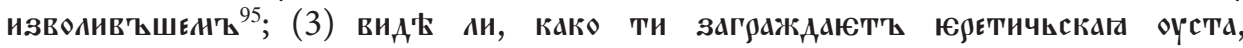

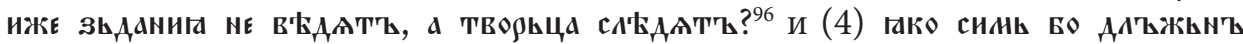

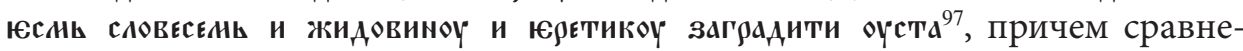
ние староболгарского текста с греческими источниками Шестоднева доказывает, что (1) и (2) не имеют греческих соответствий, а (3) и (4) явля-

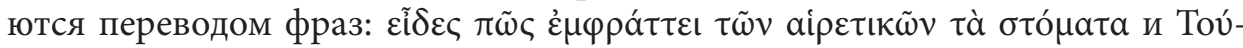

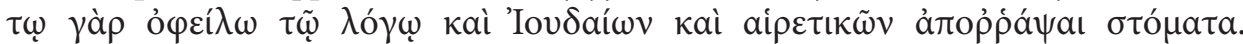
Возможно, что предложения из Слов о первом и третьем дне являются своего рода автоцитатами, парафразами предложений из Слов о четвертом и пятом дне. Козьма в свою очередь, показывая слабость аргу-

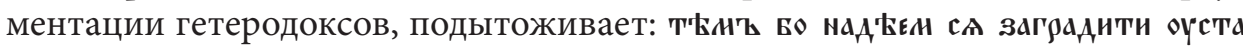

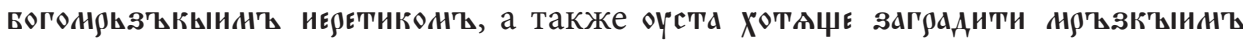

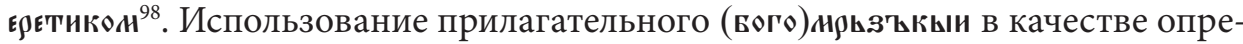
деления существительного еретик характерно для Козьмы, в то время как Иоанн Экзарх последовательно три раза использует - в качестве синонима слова нрьзъкыи и в отношении критикуемых "манихеев» - прилагательное сквљьньнъ (иначе, нежели по отношению к еретикам, к которым не добавляются дополнительные негативные определения). Заслуживает внимания факт, что эти три фрагмента не имеют греческих соответствий, поэтому их можно считать скорее личным устоявшимся мнением автора о гетеродоксах, нежели приспособлением тона высказываний к стилистике произведений, лежавших в основе компиляции ${ }^{99}$; стоит также подчеркнуть использование термина «манихеи» по отношению к ереси как таковой.

\footnotetext{
${ }_{93}^{93}$ А. ДАвИдов, ор. cit., p. 290-296.

${ }^{94}$ Hexaemeron, I, p. 53, гр.-

${ }^{95}$ Hexaemeron, III, p. 75, гр.-

${ }^{96}$ Hexaemeron, IV, p. 451-453, гр.+

${ }^{97}$ Hexaemeron, V, p. $217-219$, гр. +

${ }^{98}$ Об использовании в обоих трактатах глагола заградти с⿱㇒ в значении «закрыть, быть закрытым», а в контексте принимающего значение «приказать молчать, добиться молчания», см. А. ДАвидов, op. cit., p. 291.

${ }_{99}$ Во фрагменте, переводимым по проповеди Св. Василия, манихеи лишь неразумны/бездумны (поүстол'ъссаи наних'ћи, Hexaemeron, V, p. 105).
} 
Следующим общим элементом для антиеретических высказываний Иоанна Экзарха и Пресвитера Козьмы является включение в полемику некоторых основ иудейской веры. Они несколько раз появляются в обоих произведениях, в том числе в Шестодневе в контексте характерных для еретиков убеждений о порядке сотворения мира:

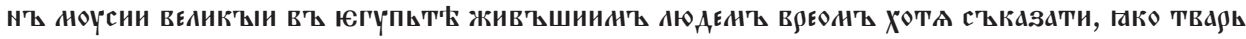

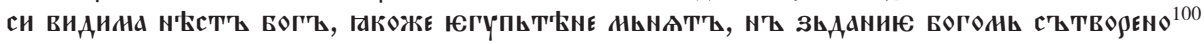

а также понимания божества:

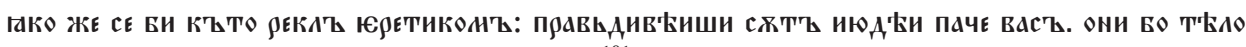

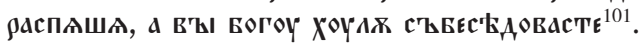

Более того, опираясь на Третье слово о сотворении мира (In mundi creationem oratio III) пера Севериана, ошибки еретиков Иоанн уравнивает с «ошибками» иудаизма:

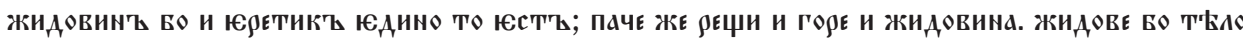

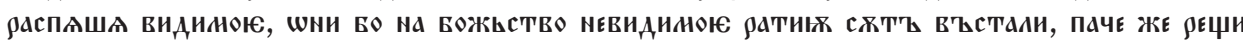
на свою стҺПАсению ${ }^{102}$;

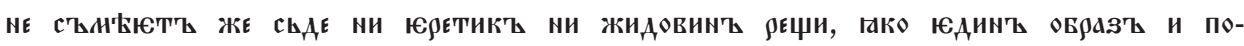
АОБЬСТВО БОЖИЮ и АГГЕльскоЮ ${ }^{103}$,

а во фрагменте Слова о шестом дне, не находящемся под влиянием византийских гексамеронов, напрямую уравнивает евреев, «врагов Божьих», с исповедниками гетеродоксальных христианских движений:

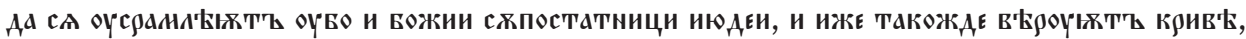

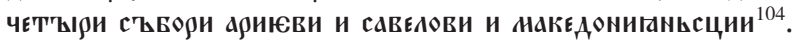

Подобным образом к евреям относится Козьма, в общей сложности семь ра3 ${ }^{105}$ упоминающий их взгляды и сравнивающий еретиков с исповедниками иудаизма. Он критически относится к тому, что евреи не узрели Божественной природы Христа (ІЯкожє вш А९євАє и жидовє почитаюште

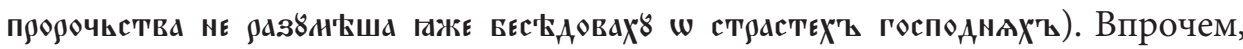
с его точки зрения заблуждения евреев меньшие, нежели убеждения ерети-

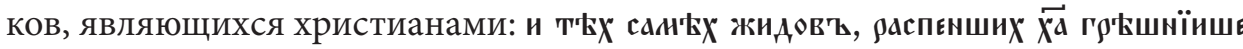

\footnotetext{
${ }^{100}$ Hexaemeron, I, p. 53, 2 p. -

${ }^{101}$ Hexaemeron, V, p. 241-243, гр. +

${ }^{102}$ Hexaemeron, V, p. 217-219, gr. +

${ }^{103}$ Hexaemeron, V, p. 219, гр. +

${ }^{104}$ Hexaemeron, VI, p. 15-17.

${ }^{105}$ А. ДАвидов, op. cit., s. 102.
} 
сชть є९єтици ${ }^{106}$. Внимания заслуживает факт, что самой тяжкой виной евреев является (по его мнению) умерщвление Спасителя:

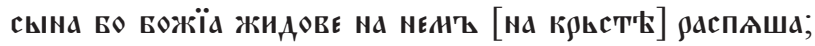

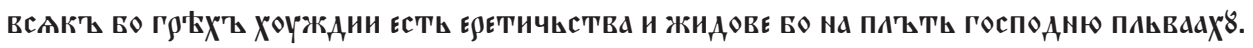

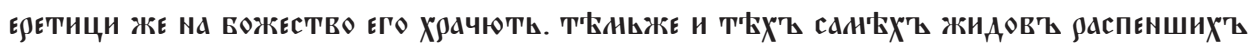
Х

Он говорит об этой вине даже в таком нейтральном контексте, как описание их поведения (на киваюште гАдвани своияи акы жидовє распинаюштє Хрнста). Из приведенных цитат, касающихся евреев, следует, что Козьма более радикален (а быть может, лишь более агрессивен) в отношении старших братьев по вере, тем более, что его высказывания целиком имеют оригинальный характер.

Цитаты и сравнения подтверждают тезис о намного более глубокой эмоциональной составляющей трактата Козьмы, что в контексте структуры и функции обоих произведений не должно удивлять: конструкция Шестоднева приводит к тому, что наличие и смысл „(анти)еретических“ фрагментов подчинены богословским рассуждениям.

Тем не менее, в обоих трактатах есть фрагмент, являющийся „общим местом“. Его включение Козьмой во введение к непосредственной полемике с еретиками вне всяких сомнений не случайно. В цитируемом выше фрагменте Слова о шестом дне Иоанн Экзарх перечисляет три тринитарные ереси: арианскую, савеллианскую и македонскую:

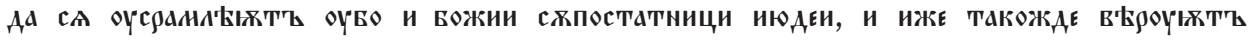

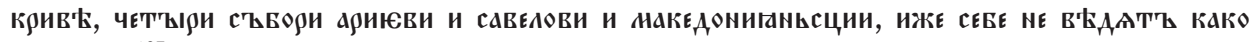
БАААХХІЕ ${ }^{107}$;

несколько раз приводит мнение манихеев:

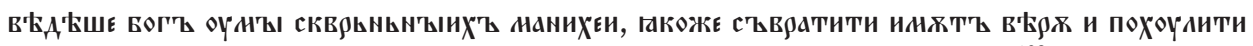

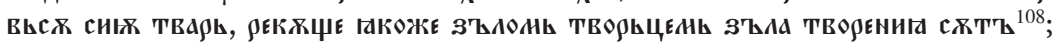

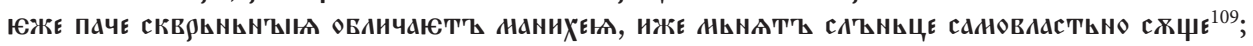

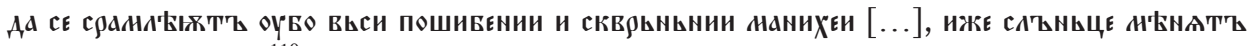
схџе сановластьно ${ }^{110}$;

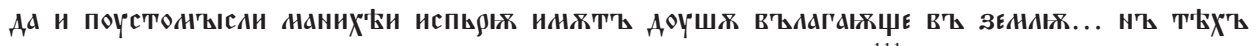

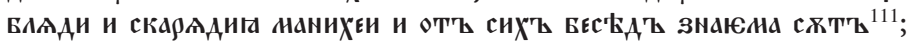

\footnotetext{
${ }^{106}$ А. ДАвидов, op. cit., p. 102.

${ }^{107}$ Hexaemeron, VI, p. $15-17$.

${ }^{108}$ Hexaemeron, III, p. 73-75, гр.-

${ }^{109}$ Hexaemeron, IV, p. 41-43, гp.-

${ }^{110}$ Hexaemeron, IV, p. 121-123, гр.-

${ }^{111}$ Hexaemeron, V, p. 105-107, гр. +
} 
а следующая цитата

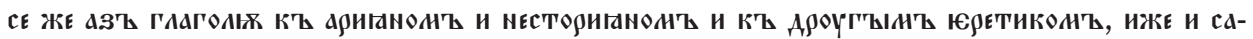

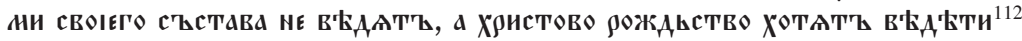

расширяет репертуар упоминаемых им христианских еретических движений посредством добавления несторианизма.

Это доказательство преимущества Иоанна над Козьмой, который был несомненно «практиком», а в его высказываниях виден опыт (непосредственных?) контактов с дуалистами. Козьма называет известных себе гетеродоксов «еретиками», не уточняя ничего далее. И только один раз он делает исключение: во введении называет различные христианские неортодоксальные движения. Связывая их названия с именами основателей, он пишет, что дьявол

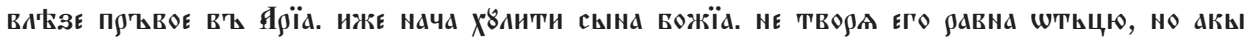

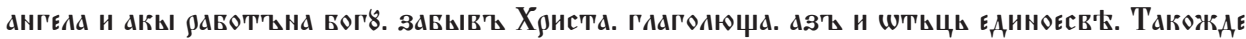

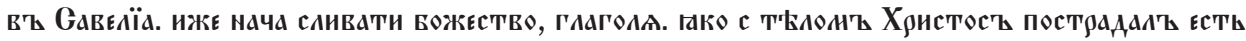

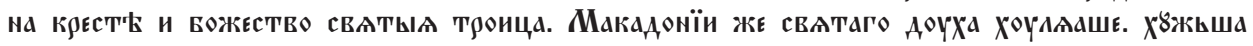

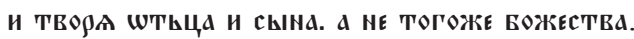

Несомненно, этот фрагмент наиболее выразительно перекликается и практически дословно повторяет указанный выше фрагмент из Иоанна. М.Г. Попруженко ищет параллели этого текста в Послании патриарха Фотия князю Борису ${ }^{113}$. Но, как видно из выше сказанного, эти же три тринитарные ереси были перечислены - в той же последовательности - Иоанном Экзархом.

Открытым остается вопрос, основывается ли совпадение на общем, использованном обоими авторами источнике, или же Козьма просто хорошо знал произведение своего предшественника. Доказанная Ю.К. Бегуновым текстологическая связь между Небесами и Беседой против богомилов наводит на мысль о большой вероятности того, что Козьма знал и использовал и другое сочинение болгарского экзарха - Шестоднев.

Приведенные примеры не дают окончательного ответа на вопрос - знал и использовал ли Пресвитер Козьма Шестоднев? И все-таки: сходства между отдельными лексемами, фразами, а также более обширными текстовыми фрагментами дает основание допустить, что они скорее генетически, а не типологически связаны, и в Беседе против богомилов могут быть открыты следы сочинения Иоанна Экзарха. Подобное утверждение - дополнительный аргу-

\footnotetext{
${ }^{112}$ Hexaemeron, I, p. 119-121, гр. -

${ }^{113}$ М.Г. ПОПрУЖЕНКО, оp. cit., p. CXCIII-CXCVI.
} 
мент в защиту гипотезы, согласно которой новый пресвитер и экзарх Иоанн, упомянутый в конце произведения Козьмы - это именно Иоанн Экзарх ${ }^{114}$.

Просмотр тех фрагментов из Шестоднева Иоанна Экзарха, в которых упоминаются еретики, манихеи, язычники, язычники-славяне или тринитарные и христологические ереси (арианство, савеллианство, несторианство), дает возможность сделать несколько выводов, относящихся к «предыстории» богомилизма на болгарской земле.

Староболгарский перевод/компиляция Иоанна Экзарха приводит важные сведения о космогонии, теологической доктрине и литургических практиках неоманихеев в византийско-славянском мире. В большинстве случаев речь идет о переводе греческих текстов, созданных в раннехристианскую эпоху, когда манихейство, тринитарные и христологические отклонения от ортодоксии все еще были актуальны. Оригинальные дополнения в Шестодневе и фрагменты, представляющие свободный перевод/компиляцию, свидетельствуют, однако, об актуальности антидуалистической полемики также в этот более поздний период византийско-славянской религиозной и культурной общности: древние гностические и манихейские представления, адаптированные в позднейших дуалистических ересях, такие как мессалианство и павликианство, сочетаемые с тринитарными и христологическими отклонениями от официальной догмы, проникают в I Болгарское царство и превращаются в благоприятную почву для появления богомилизма. В этом смысле староболгарский Шестоднев становится важным свидетельством о предшественниках „болгарской ереси”.

Оригинальные добавки и свободные переводы/компиляции некоторых фрагментов изобличают характерные для всех средневековых неоманихейских доктрин „общие места”: дуалистический миф о сотворении, веру в сатану как „первородного сына Бога” и связанные с ней тринитарные и христологические отклонения от официальной догматики. Особого внимания заслуживает фрагмент, относящийся к Трисвятому. Отрицание отдельных элементов Литургии Верных, подтвержденное и в позднейших византийских источниках, свидетельствует об одном более дифференцированном отношении дуалистов к официальному ритуалу, то есть не целостное его отрицание, а неприятие тех элементов, которые по их мнению восхваляют

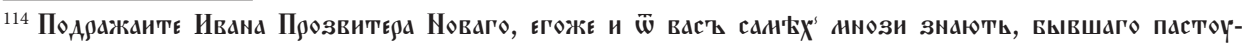

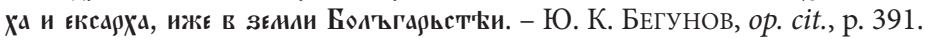


ветхозаветного Бога и противоречат неоманихейским представлениям о сотворении и избавлении.

Упоминание языческого славянского солярного культа необходимо рассматривать не только в связи с обвинениями манихеев и славян в идолопоклонстве, но и в более широком контексте отрицания античных астрологических верований и гадательных практик - в контексте полемики, которой посвящена значительная часть Слова о четвертом дне.

Сравнение отдельных лексем, фраз, а также больших текстовых единиц между Шестодневом и Беседой против богомилов дает возможность допускать, что Пресвитер Козьма знал сочинение своего предшественника и использовал его при составлении своего антиеретического произведения.

Перевод: Иван Н. Петров

\begin{abstract}
Information on dualist heresies and pagan beliefs in John Exarch's Hexameron (Šestodnev). The article aims to present and analyze those passages of the Hexameron (Šestodnev) in which 'heretics,' 'Manichaeans,' 'pagans' or 'pagan Slavs' are mentioned. The fragments are compared with their Greek counterparts (as long as these exist); the Old Bulgarian texts (especially those that can be considered original additions or loose compilations) are utilized for interpreting certain elements of heterodox doctrines common to Manichaeism, Paulicianism, Massalianism and Bogomilism.

The Old Bulgarian translation/compilation by John Exarch supplies important information on the cosmology, theological doctrine and liturgical life of the Neo-Manichaeans within the ByzantineSlavic world. The original additions and passages that can be seen as loose translations or compilations testify to the relevance of anti-dualist polemics even in the later periods of the Byzantine-Slavic religious community. The old Gnostic and Manichaean concepts, adapted by later dualist heresies (as e.g. Massalianism and Paulicianism), coupled with Trinitarian and Christological deviations from the official dogma, infiltrate the $1^{\text {st }}$ Bulgarian Empire and provide a hospitable environment for the appearance of Bogomilism. In this sense, the Old Bulgarian Hexameron turns out to be an important source of information on the predecessors of the 'Bulgarian heresy'.

The original additions and loose translations/compilations of certain passages uncover some 'common areas' characteristic of all medieval Neo-Manichaean doctrines: the dualist creation myth, the belief in Satan as God's 'first-born son' and the related Trinitarian and Christological departures from the prescribed dogma. Especially noteworthy is the passage referring to the Trisagion (Trisvetoe). The rejection of particular elements of the Liturgy of the Faithful attests to the dualists' more diversified attitude towards the official ritual - not an indiscriminate renunciation, but the exclusion of those elements that were considered to praise the Old Testament God and to be irreconcilable with the Neo-Manichaean beliefs concerning creation and forgiveness.

The mentioning of a Slavic pagan sun cult should be analyzed not only in connection with the charges against Manichaeans and Slavs concerning idolatry, but also in a wider context of the refutation of antique astrological beliefs and soothsaying practices.

The comparison of particular lexemes, phrases and larger textual units in John Exarch's Hexameron on the one hand and the Sermon Against the Heretics on the other makes it possible to conjecture that Cosmas the Priest was familiar with his predecessor's work and made use of it when composing his own anti-heretic text.
\end{abstract}


Ключевые слова: Средневековые дуалистические ереси, славянская и византийская литература, греческий и славянский Шестоднев, болгарские еретики.

Keywords: Medieval dualist heresies, Old Slavonic Literature, Hexaemeron, Bulgarian medieval heretics.

Georgi Minczew

Katedra Filologii Słowiańskiej

Wydział Filologiczny, Uniwersytet Łódzki

ul. Pomorska 171/173, 90-236 Łódź

georgi.minczew@uni.lodz.pl

Małgorzata Skowronek

Katedra Filologii Słowiańskiej

Wydział Filologiczny, Uniwersytet Łódzki

ul. Pomorska 171/173, 90-236 Łódź

malgorzata.skowronek@uni.lodz.pl 